\title{
SYMPTOMATOLOGY OF FEMALE PATIENTS ATTENDING MOBILE MEDICAL CLINICS IN A RURAL BLOCK IN TAMILNADU
}

\author{
LOGARAJ M, SATHIYANARAYANAN S*, BALAJI R
}

Department of Community Medicine, SRM Medical College Hospital and Research Centre, SRM Institute of Science \& Technology, Kancheepuram, Tamil Nadu, India. Email: drsatyavk@gmail.com

Received: 08 June 2018, Revised and Accepted: 12 June 2018

\section{ABSTRACT}

Objectives: The objectives of the study were to find out the prevalence of "symptoms not elsewhere classified" under the International Classification of Diseases, Tenth Revision, Clinical Modification among the female patients attending mobile medical clinics.

Methods: A cross-sectional study was carried out among 7,124 female patients who attended weekly mobile medical clinics in a rural block in Tamil Nadu. Sociodemographic variables, symptomatology, patient history, and clinical examination details were collected using a pre-tested structured questionnaire.

Results: The five common symptoms affecting the study population were myalgia (18.3\%), nasal congestion (13.6\%), headache (13.1\%), lumbar pain $(12.5 \%)$, and knee pain $(9.3 \%)$. The systems commonly affected among the female patients were in the order of general symptoms and signs (R50-R69), circulatory and respiratory systems (R00-R09), and Nervous and Musculoskeletal Systems (R25-R29). In the age group of 10-19 years and 20-39 years, the most common symptom was headache (25.2\% and $18.8 \%$, respectively). In the age group of $40-59$ years and 60 years and above, it was myalgia (24.2\% and $32.3 \%$, respectively).

Conclusion: As pain being most common symptoms, an appropriate strategy and guidelines have to be developed to manage the problem of pain at primary care level.

Keywords: Symptomatology, Females, Medical clinics, Rural.

(C) 2018 The Authors. Published by Innovare Academic Sciences Pvt Ltd. This is an open access article under the CC BY license (http://creativecommons. org/licenses/by/4. 0/) DOI: http://dx.doi.org/10.22159/ajpcr.2018.v11i10.20585

\section{INTRODUCTION}

Globally, of all the patients present with symptoms, only a small proportion $(15 \%)$ of the patients present with identifiable organic causes. Remaining $10 \%$ of patients present with psychological causes and $75 \%$ with unknown causes [1]. Long-term medical conditions are imposing an increasing burden on health-care systems [2]. In India, the majority of the population seeks health care at the Primary Health Centers, and most of these symptoms are managed by paramedical staffs. The study of the nature of the symptoms and their clustering occurring at community level helps us to manage these symptoms at primary care level. Knowledge on the epidemiology of symptoms at primary care level can contribute to wider improvements in health and health-care services, through a better understanding of disease etiology, use of health care services and the role of different healthcare interventions. At the community level, we need to know the magnitude of the symptoms and its distribution based on age and sex. Studies have repeatedly shown that most symptoms experienced in the community are managed without seeking proper health care [3]. Elderly patients commonly have multiple pathologies which may lead to poly-pharmacy and can alter the pharmacokinetics and pharmacodynamics, which leads to adverse drug reactions from inappropriate medication [4]. Thus, a population-based approach is needed for better understanding of the frequency, pattern, and management of the presenting symptoms at primary care level. However, not many studies have been done at the community level to study the morbidities among women. This study was done to find out the prevalence of "symptoms not elsewhere classified" under The International Classification of Diseases, Tenth Revision, Clinical Modification (ICD-10-CM) among the female patients attending mobile medical clinics.

\section{METHODS}

A cross-sectional study was conducted among the female patients who had participated in our weekly medical clinics conducted in villages of Kattankulathur block, Kancheepuram district, Tamil Nadu, for a period of 1 year from June 2014 to May 2015. All females who have attended our medical clinics were included in the study. The physical symptoms for which the patients were seeking medical care were classified under the 2016/17 ICD-10-CM Diagnosis Codes R00-R99 - Symptoms, signs and abnormal clinical and laboratory findings, not elsewhere classified. The study was approved by the Institutional Ethics Committee. Data were entered into Microsoft Excel spreadsheets and analyzed using standard statistical software packages. Descriptive data were presented as simple proportions. The Chi-square test was used for analyzes of categorical variables.

\section{RESULTS}

This study was undertaken to find out the prevalence of symptoms findings, not elsewhere classified under the ICD-10-CM classification among the female patients attending our mobile medical clinic. This classification was used because more specific diagnosis could not be made and point, perhaps equal to two or more diseases or two or more systems of the body at the mobile clinic. Their causes could not be determined and cases referred to a tertiary care hospital for investigation or treatment before the diagnosis was made, and also cases were included in which a more precise diagnosis was not available for any other reason.

A total of 7,124 female patients attended our mobile medical clinics. The mean age \pm standard deviation of the study participants was 46.4 \pm 1.87 . Among them, $11.4 \%(811 / 7124)$ belonged to children of 
$0-9$ years, 9.6\% (683/7124) belonged to adolescents of 10-19 years, $30.8 \%(2197 / 7124)$ belonged to young adults of $20-39$ years, $32.1 \%$ (2290/7124) belonged to middle age of $40-59$ years, and $15.9 \%$ (1143/7124) belonged to a geriatric group of 60 years and above. All the study subjects reported one or more symptoms based on which they were classified.

Table 1 depicts the distribution of the symptoms of cardiovascular and respiratory systems. Among them, nasal congestion (13.6\%) is the most common symptom reported among the study subjects. In children, nasal congestion (41.3\%) and cough $(13.7 \%)$ were more common symptoms compared to other symptoms and another age group. This was statistically significant for both symptoms $(\mathrm{p}<0.001)$. Throat pain was more common $(5.5 \%)$ in adolescents compared to other age groups, and it was statically significant $(\mathrm{p}<0.001)$. The chest pain was most commonly reported symptom in young adults compared to other age groups, and it was statistically significant $(p=0.02)$. Dyspnea $(4.7 \%)$ and hypertension $(1.3 \%)$ were more commonly reported in the geriatric age group, compared to other age groups and it was statistically significant $(\mathrm{p}<0.001)$. The proportion of females with symptoms of the respiratory system was high in children with $57.2 \%$ compared to other age group, and this was found to be statistically significant $(\mathrm{p}<0.001)$.

Table 2 shows the prevalence of symptoms involving the digestive system and abdomen among the female patients attending the mobile clinic. The most common symptom of the digestive system was an abdominal pain $(7.8 \%)$ followed by epigastric pain (4.5\%). Vomiting $(0.8 \%)$ and diarrhea $(0.5 \%)$ were more common in children compared to another age group, and it was statistically significant for vomiting $(\mathrm{p}=0.003)$. More of abdominal pain $(17.7 \%)$ and dental caries $(3.5 \%)$ were reported in adolescent age group compared to another age group, and it was statistically significant $(\mathrm{p}<0.001)$. The proportion of lower abdominal pain was more $(1 \%)$ in the middle age group compared to other age groups, and it was statistically significant. Epigastric pain $(5.8 \%)$ was more common young adult age group compared to another age group, and it was statically significant $(\mathrm{p}<0.001)$. Overall, the symptoms of digestive system and abdomen were more common

Table 1: Symptoms and signs involving the circulatory and respiratory systems among the study subjects (R00-R09)

\begin{tabular}{|c|c|c|c|c|c|c|c|}
\hline Symptoms & $\begin{array}{l}\text { 0-9 years } \\
n=811(11.4)\end{array}$ & $\begin{array}{l}10-19 \text { years } \\
n=683(9.6)\end{array}$ & $\begin{array}{l}20-39 \text { years } \\
n=2197(30.8)\end{array}$ & $\begin{array}{l}40-59 \text { years } \\
n=2290(32.1)\end{array}$ & $\begin{array}{l}\geq 60 \text { years } \\
n=1143(15.9)\end{array}$ & $\begin{array}{l}\text { Total } \\
n=7124\end{array}$ & $\begin{array}{l}\chi^{2}, \mathrm{df} \text { and } \\
\mathrm{p} \text { value }\end{array}$ \\
\hline Nasal congestion & 335 (41.3) & 121 (17.7) & $289(13.2)$ & $154(6.7)$ & $68(5.9)$ & $967(13.6)$ & $\begin{array}{l}\chi^{2}=690, \mathrm{df}=4 \\
\mathrm{p}<0.001^{*}\end{array}$ \\
\hline Cough & $111(13.7)$ & $50(7.3)$ & $141(6.4)$ & $117(5.1)$ & $68(5.9)$ & $487(6.9)$ & $\begin{array}{l}\chi^{2}=72.8, d f=4 \\
p<0.001^{*}\end{array}$ \\
\hline Throat pain & $14(1.7)$ & $22(3.2)$ & $120(5.5)$ & $80(3.5)$ & $16(1.4)$ & $252(3.6)$ & $\begin{array}{l}\chi^{2}=42.7, d f=4 \\
p<0.001^{*}\end{array}$ \\
\hline Chest pain & $2(0.2)$ & $5(0.7)$ & $35(1.6)$ & $36(1.6)$ & $16(1.4)$ & $94(1.3)$ & $\begin{array}{l}\chi^{2}=11.4, d f=4 \\
p=0.022 *\end{array}$ \\
\hline Hypertension & 0 & 0 & $2(0.1)$ & $10(0.4)$ & $15(1.3)$ & $27(0.4)$ & $\begin{array}{l}\chi^{2}=37.1, d f=4 \\
p<0.001^{*}\end{array}$ \\
\hline Palpitations & 0 & $1(0.1)$ & $6(0.3)$ & $4(0.2)$ & $1(0.1)$ & $12(0.2)$ & $\begin{array}{l}\chi^{2}=3.27, d f=4 \\
p=0.514\end{array}$ \\
\hline Total & $466(57.4)$ & 208 (30.5) & $648(29.5)$ & $470(20.6)$ & 238 (21.7) & $2030(27.1)$ & $\begin{array}{l}\chi^{2}=441, d f=4 \\
p<0.001^{*}\end{array}$ \\
\hline
\end{tabular}

Figures in parenthesis indicate percentage; $\chi^{2}$ value, df-degrees of freedom, *Significant as $P<0.05$ using Chi-square test

Table 2: Symptoms and signs involving the digestive system and abdomen among the study subjects (R10-R19)

\begin{tabular}{|c|c|c|c|c|c|c|c|}
\hline Symptoms & $\begin{array}{l}0-9 \text { years } \\
n=811(11.4)\end{array}$ & $\begin{array}{l}10-19 \text { years } \\
n=683(9.6)\end{array}$ & $\begin{array}{l}20-39 \text { years } \\
n=2197(30.8)\end{array}$ & $\begin{array}{l}40-59 \text { years } \\
n=2290(32.1)\end{array}$ & $\begin{array}{l}\geq 60 \text { years } \\
n=1143(15.9)\end{array}$ & $\begin{array}{l}\text { Total } \\
\mathrm{n}=7124\end{array}$ & $\begin{array}{l}\chi^{2}, \mathrm{df} \text { and } \\
\mathrm{p} \text { value }\end{array}$ \\
\hline Generalized abdominal pain & $58(7.2)$ & $121(17.7)$ & $182(8.3)$ & $138(6.0)$ & $60(5.2)$ & $559(7.8)$ & $\begin{array}{l}\chi^{2}=114, \mathrm{df}=4 \\
\mathrm{p}=0.001^{*}\end{array}$ \\
\hline Epigastric pain & $1(0.1)$ & $20(2.9)$ & $107(4.9)$ & $132(5.8)$ & $52(4.5)$ & $312(4.4)$ & $\begin{array}{l}\chi^{2}=50.2, \mathrm{df}=4 \\
\mathrm{p}<0.001^{*}\end{array}$ \\
\hline Dental caries & $23(2.8)$ & $24(3.5)$ & $9(0.4)$ & $7(0.3)$ & 0 & $63(0.9)$ & $\begin{array}{l}\chi^{2}=114, \mathrm{df}=4 \\
\mathrm{p}<0.001^{*}\end{array}$ \\
\hline Lower abdominal pain & 0 & $4(0.6)$ & $22(1.0)$ & $11(0.5)$ & $1(0.1)$ & $38(0.5)$ & $\begin{array}{l}\chi^{2}=17.9, \mathrm{df}=4 \\
\mathrm{p}=0.001^{*}\end{array}$ \\
\hline Vomiting & $6(0.8)$ & $1(0.1)$ & $18(0.8)$ & $3(0.1)$ & $3(0.3)$ & $31(0.4)$ & $\begin{array}{l}\chi^{2}=16.2, \mathrm{df}=4 \\
\mathrm{p}=0.003^{*}\end{array}$ \\
\hline Constipation & $1(0.1)$ & $1(0.1)$ & $5(0.2)$ & $11(0.5)$ & $2(0.2)$ & $20(0.3)$ & $\begin{array}{l}\chi^{2}=5.1, d f=4 \\
p=0.278\end{array}$ \\
\hline Diarrhea & $4(0.5)$ & $3(0.4)$ & $3(0.1)$ & $2(0.1)$ & $4(0.3)$ & $16(0.2)$ & $\begin{array}{l}\chi^{2}=7.5, \mathrm{df}=4 \\
\mathrm{p}=0.112\end{array}$ \\
\hline Indigestion & 0 & 0 & $3(0.1)$ & $3(0.1)$ & $2(0.2)$ & $8(0.1)$ & $\begin{array}{l}\chi^{2}=2.2, \mathrm{df}=4 \\
\mathrm{p}=0.687\end{array}$ \\
\hline Malena & 0 & 0 & $3(0.1)$ & 0 & 0 & $3(0.05)$ & $\begin{array}{l}\chi^{2}=6.7, d f=4 \\
p=0.151\end{array}$ \\
\hline Total & $93(11.5)$ & $174(25.5)$ & $358(16.3)$ & $314(13.7)$ & $126(11.0)$ & 1065 (14.9) & $\begin{array}{l}\chi^{2}=87, \mathrm{df}=4 \\
\mathrm{p}<0.001^{*}\end{array}$ \\
\hline
\end{tabular}

Figures in parenthesis indicate percentage; $\chi^{2}$ value, df-degrees of freedom, ${ }^{*}$ Significant as $P<0.05$ using Chi-square test 
(25.5\%) in young adults compared to another age group, and it was found to be statistically significant $(\mathrm{p}<0.001)$.

Table 3 shows symptoms and signs involving the skin and subcutaneous tissue among female subjects. Common symptoms being rash and other non-specific skin eruption (1.5\%) followed by itching any site $(1.4 \%)$. The prevalence of rash and other non-specific skin eruption was more among children and adolescents compared to other age group and itching any site was more among elderly above the age of 60 years. Acne was reported only among the adolescent (1.5\%).
Table 4 depicts symptoms and signs involving the nervous and musculoskeletal systems among females. The common symptom being myalgia (18.3\%) followed by low back pain (16.9\%) and knee pain $(9.3 \%)$. As the age increases, the prevalence of myalgia, knee pain, hip pain, and leg pain also increases and it was found statistically significant. About $32.3 \%, 15.4 \%, 1.8 \%$, and $6.9 \%$ of the elderly above the age of 60 years reported with symptoms of myalgia, knee pain, hip pain, and leg pain, respectively. Overall, $95.6 \%$ of the women in the age group of 4059 years and $90.6 \%$ of women in the age group of above 60 years had symptoms of nervous and musculoskeletal symptoms.

Table 3: Symptoms and signs involving the skin and subcutaneous tissue among the study subjects (R20-R23)

\begin{tabular}{|c|c|c|c|c|c|c|c|}
\hline Symptoms & $\begin{array}{l}\text { 0-9 years } \\
n=811(11.4)\end{array}$ & $\begin{array}{l}10-19 \text { years } \\
n=683(9.6)\end{array}$ & $\begin{array}{l}20-39 \text { years } \\
n=2197(30.8)\end{array}$ & $\begin{array}{l}40-59 \text { years } \\
n=2290(32.1)\end{array}$ & $\begin{array}{l}\geq 60 \text { years } \\
n=1143(15.9)\end{array}$ & $\begin{array}{l}\text { Total } \\
n=7124\end{array}$ & $\begin{array}{l}\chi^{2}, \mathbf{d f} \\
\text { and } P \text { value }\end{array}$ \\
\hline $\begin{array}{l}\text { Rash and other } \\
\text { non-specific skin eruption }\end{array}$ & $27(3.3)$ & $20(2.9)$ & $34(1.5)$ & $21(0.9)$ & $7(0.6)$ & $109(1.5)$ & $\begin{array}{l}\chi^{2}=38.4, \mathrm{df}=4 \\
p<0.001^{*}\end{array}$ \\
\hline Itching any site & $14(1.7)$ & $10(1.5)$ & $26(1.2)$ & $30(1.4)$ & $24(2.0)$ & $104(1.4)$ & $\begin{array}{l}\chi^{2}=5.2, d f=4 \\
p=0.270\end{array}$ \\
\hline Numbness & $1(0.1)$ & 0 & $9(0.4)$ & $6(0.3)$ & $3(0.3)$ & $19(0.2)$ & $\begin{array}{l}\chi^{2}=4.1, d f=4 \\
p=0.387\end{array}$ \\
\hline Acne & 0 & $10(1.5)$ & 0 & 0 & 0 & $10(0.1)$ & $\begin{array}{l}\chi^{2}=91.4, \mathrm{df}=4 \\
\mathrm{p}<0.001^{*}\end{array}$ \\
\hline Allergy & 0 & $1(0.1)$ & $5(0.2)$ & $1(0.05)$ & 0 & $7(0.1)$ & $\begin{array}{l}\chi^{2}=6.5, d f=4 \\
p=0.163\end{array}$ \\
\hline Swelling lower limb & $1(0.1)$ & 0 & $1(0.05)$ & $2(0.1)$ & 0 & $4(0.05)$ & $\begin{array}{l}\chi^{2}=2.1, d f=4 \\
p=0.714\end{array}$ \\
\hline Abscess & 0 & 0 & $2(0.1)$ & 0 & 0 & $2(0.02)$ & $\begin{array}{l}\chi^{2}=76.1, \mathrm{df}=4 \\
\mathrm{p}<0.001^{*}\end{array}$ \\
\hline Total & $43(5.3)$ & $41(6.0)$ & $84(3.8)$ & $64(2.8)$ & $36(3.1)$ & $268(4.5)$ & $\begin{array}{l}\chi^{2}=21.9, \mathrm{df}=4 \\
\mathrm{p}<0.001^{*}\end{array}$ \\
\hline
\end{tabular}

Figures in parenthesis indicate percentage; $\chi^{2}$ value, df-degrees of freedom, *Significant at $P<0.05$ using Chi-square test

Table 4: Symptoms and signs involving the nervous and musculoskeletal systems among the study subjects (R25-R29)

\begin{tabular}{|c|c|c|c|c|c|c|c|}
\hline Symptoms & $\begin{array}{l}\text { 0-9 years } \\
n=811(11.4)\end{array}$ & $\begin{array}{l}10-19 \text { years } \\
n=683(9.6)\end{array}$ & $\begin{array}{l}20-39 \text { years } \\
n=2197(30.8)\end{array}$ & $\begin{array}{l}40-59 \text { years } \\
n=2290(32.1)\end{array}$ & $\begin{array}{l}\geq 60 \text { years } \\
1143(15.9)\end{array}$ & $\begin{array}{l}\text { Total } \\
7124 \\
\end{array}$ & $\begin{array}{l}\chi^{2}, \mathrm{df} \text { and } \\
\mathrm{p} \text { value }\end{array}$ \\
\hline Myalgia & $4(0.5)$ & $17(2.5)$ & $362(16.5)$ & $554(24.2)$ & $369(32.3)$ & 1307 (18.3) & $\begin{array}{l}\chi^{2}=493, \mathrm{df}=4 \\
\mathrm{p}<0.001^{*}\end{array}$ \\
\hline Low back pain & $22(2.7)$ & $174(25.5)$ & $514(23.4)$ & 375 (16.4) & $122(10.7)$ & 1207 (16.9) & $\begin{array}{l}\chi^{2}=249, \mathrm{df}=4 \\
\mathrm{p}<0.001^{*}\end{array}$ \\
\hline Knee pain & $4(0.5)$ & $7(1.0)$ & $130(5.9)$ & 348 (15.2) & $176(15.4)$ & $665(9.3)$ & $\begin{array}{l}\chi^{2}=304, d f=4 \\
p<0.001^{*}\end{array}$ \\
\hline Pain in leg, unspecified & $5(0.6)$ & $9(1.3)$ & $151(6.9)$ & $174(7.6)$ & $79(6.9)$ & $418(5.9)$ & $\begin{array}{l}\chi^{2}=84.8, \mathrm{df}=4 \\
\mathrm{p}<0.001^{*}\end{array}$ \\
\hline Joint pain & $4(0.5)$ & $4(0.6)$ & $89(4.1)$ & $166(7.2)$ & $86(7.5)$ & 349 (4.9) & $\begin{array}{l}\chi^{2}=109, \mathrm{df}=4 \\
\mathrm{p}<0.001^{*}\end{array}$ \\
\hline Shoulder pain & $7(0.9)$ & $3(0.5)$ & $91(4.1)$ & $165(7.2)$ & $60(5.2)$ & $326(4.6)$ & $\begin{array}{l}\chi^{2}=90.4, \mathrm{df}=4 \\
\mathrm{p}<0.001^{*}\end{array}$ \\
\hline Pain in arm, unspecified & 0 & $1(0.1)$ & $25(1.1)$ & $51(2.2)$ & $7(0.6)$ & $84(1.2)$ & $\begin{array}{l}\chi^{2}=40.7, \mathrm{df}=4 \\
\mathrm{p}<0.001^{*}\end{array}$ \\
\hline Hip pain & 0 & $1(0.1)$ & $17(0.8)$ & $38(1.7)$ & $21(1.8)$ & $76(1.1)$ & $\begin{array}{l}\chi^{2}=29.7, \mathrm{df}=4 \\
\mathrm{p} \leq 0.001^{*}\end{array}$ \\
\hline Joint swelling & $2(0.2)$ & $3(0.4)$ & $14(0.6)$ & $21(0.9)$ & $12(1.0)$ & $52(0.7)$ & $\begin{array}{l}\chi^{2}=6.4, d f=4 \\
p=0.172\end{array}$ \\
\hline Foot pain & $3(0.4)$ & $3(0.4)$ & $8(0.4)$ & $5(0.2)$ & $2(0.1)$ & $21(0.3)$ & $\begin{array}{l}\chi^{2}=2.0, \mathrm{df}=4 \\
p=0.733\end{array}$ \\
\hline Injury NOS & $6(0.7)$ & 0 & $5(0.2)$ & $4(0.2)$ & 0 & $15(0.2)$ & $\begin{array}{l}\chi^{2}=14.8, \mathrm{df}=4 \\
\mathrm{p}=0.005^{*}\end{array}$ \\
\hline Total & $65(8.0)$ & $237(34.7)$ & 1645 (74.9) & $2189(95.6)$ & $1036(90.6)$ & $5172(72.6)$ & $\begin{array}{l}\chi^{2}=299, \mathrm{df}=4 \\
\mathrm{p}<0.001^{*}\end{array}$ \\
\hline
\end{tabular}

Figures in parenthesis indicate percentage; $\chi^{2}$ value, df-degrees of freedom, ${ }^{*}$ Significant as $P<0.05$ using Chi-square test 
Table 5 shows symptoms involving signs involving cognition, perception, emotional state, and behavior) and symptoms and signs involving the genitourinary system. The giddiness was the most common symptoms among females (4.0\%). The prevalence of giddiness was more common among elderly above the age of 60 years (5.8\%) compared to other age group, and it was found statistically significant $(\mathrm{p}<0.001)$. White discharge $(0.9 \%)$ was the most common symptom among women under the genitourinary system. The symptoms white discharge $(2.3 \%)$

Table 5: Symptoms and signs involving cognition, perception, emotional state and behavior (R40-R46), and genitourinary system among the study subjects (R30-R39)

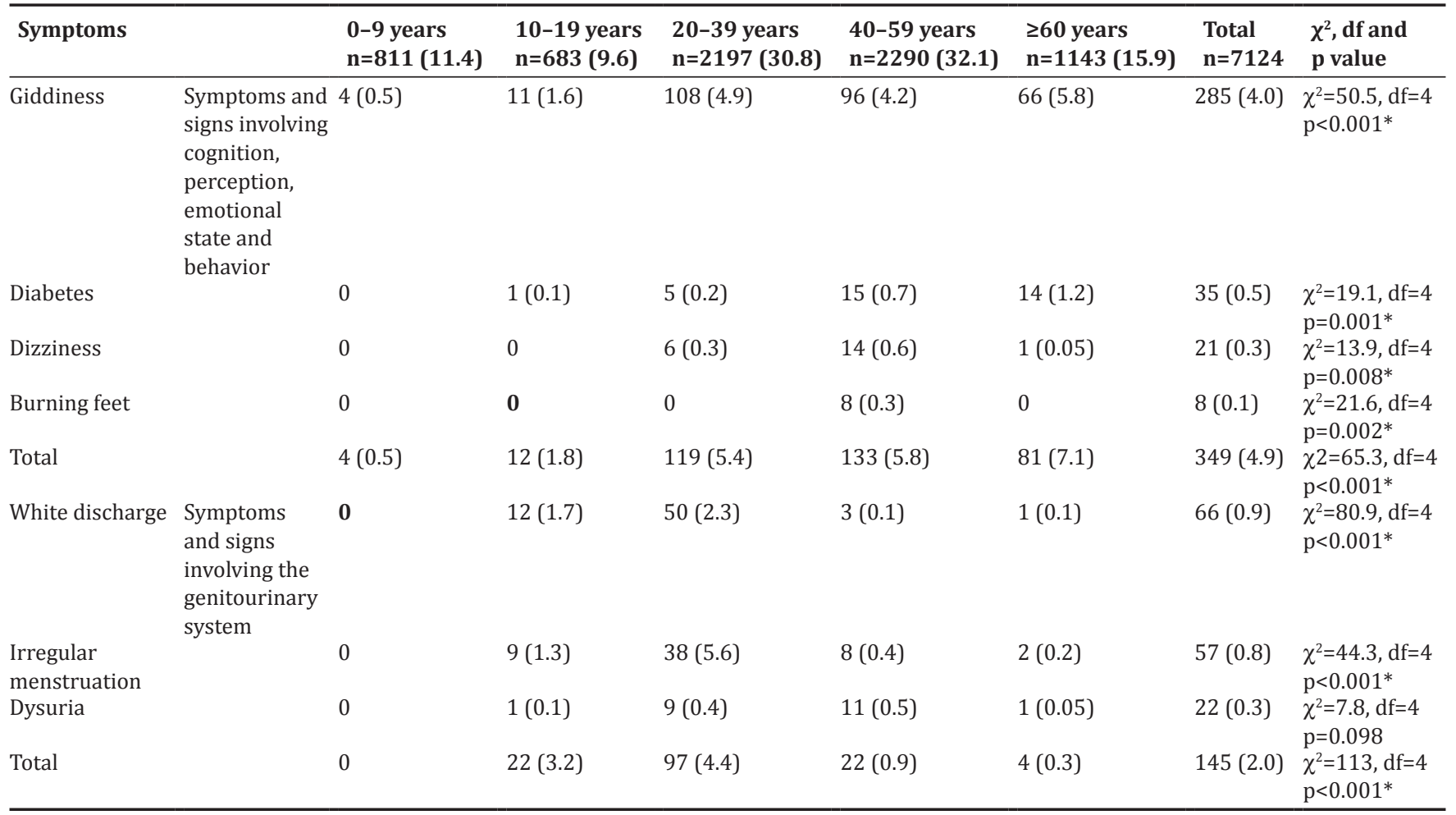

Figures in parenthesis indicate percentage; $\chi^{2}$ value, df-degrees of freedom, ${ }^{*}$ Significant as $P<0.05$ using Chi-square test

Table 6: General symptoms and signs among the study subjects (R50-R69)

\begin{tabular}{|c|c|c|c|c|c|c|c|}
\hline Symptoms & $\begin{array}{l}\text { 0-9 years } \\
n=811(11.4)\end{array}$ & $\begin{array}{l}10-19 \text { years } \\
n=683(9.6)\end{array}$ & $\begin{array}{l}20-39 \text { years } \\
n=2197(30.8)\end{array}$ & $\begin{array}{l}40-59 \text { years } \\
n=2290(32.1)\end{array}$ & $\begin{array}{l}\geq 60 \text { years } \\
1143(15.9)\end{array}$ & $\begin{array}{l}\text { Total } \\
7124\end{array}$ & $\begin{array}{l}\chi^{2}, \text { df and } \\
\text { p value }\end{array}$ \\
\hline Headache & $17(2.1)$ & $172(25.2)$ & 412 (18.8) & $268(11.7)$ & $67(5.9)$ & $936(13.4)$ & $\begin{array}{l}\chi^{2}=291, \mathrm{df}=4 \\
p<0.001^{*}\end{array}$ \\
\hline Fever unspecified & $161(19.9)$ & $49(7.2)$ & $107(4.9)$ & $76(3.3)$ & $37(3.2)$ & $430(6.0)$ & $\begin{array}{l}\chi^{2}=325, \mathrm{df}=4 \\
\mathrm{p}<0.001^{*}\end{array}$ \\
\hline Weakness & $3(0.4)$ & $5(0.7)$ & $78(3.5)$ & $62(2.7)$ & $48(4.2)$ & $196(2.7)$ & $\begin{array}{l}\chi^{2}=41.8, \mathrm{df}=4 \\
\mathrm{p}<0.001^{*}\end{array}$ \\
\hline Epiphora (watering eye) & $15(1.8)$ & $9(1.3)$ & $12(0.5)$ & $27(1.2)$ & $35(3.1)$ & $98(1.4)$ & $\begin{array}{l}\chi^{2}=37.1, \mathrm{df}=4 \\
\mathrm{p}<0.001^{*}\end{array}$ \\
\hline Tooth pain & $14(1.7)$ & $12(1.8)$ & $25(1.1)$ & $14(0.6)$ & $8(0.7)$ & $73(1.02)$ & $\begin{array}{l}\chi^{2}=12.9, \mathrm{df}=4 \\
\mathrm{p}=0.012^{*}\end{array}$ \\
\hline Ear pain & $18(2.2)$ & $14(2.0)$ & $18(0.8)$ & $14(0.6)$ & $8(0.7)$ & $72(1.01)$ & $\begin{array}{l}\chi^{2}=24.8, \mathrm{df}=4 \\
\mathrm{p}<0.001^{*}\end{array}$ \\
\hline Eye pain & $2(0.2)$ & $6(0.9)$ & $12(0.5)$ & $26(1.2)$ & $20(1.7)$ & $66(0.9)$ & $\begin{array}{l}\chi^{2}=17.1, \mathrm{df}=4 \\
\mathrm{p}=0.002^{*}\end{array}$ \\
\hline Loss of appetite & $20(2.5)$ & $5(0.7)$ & $10(0.5)$ & $17(0.7)$ & $10(0.9)$ & $62(0.9)$ & $\begin{array}{l}\chi^{2}=28.9, \mathrm{df}=4 \\
\mathrm{p}<0.001^{*}\end{array}$ \\
\hline Hearing loss & $1(0.1)$ & $3(0.4)$ & $2(0.1)$ & $3(0.1)$ & $3(0.3)$ & $12(0.2)$ & $\begin{array}{l}\chi^{2}=4.6, d f=4 \\
p=0.325\end{array}$ \\
\hline Abnormal weight loss & $1(0.1)$ & 0 & $4(0.2)$ & $1(0.03)$ & 0 & $6(0.1)$ & $\begin{array}{l}\chi^{2}=4.63, \mathrm{df}=4 \\
p=0.327\end{array}$ \\
\hline Weight gain & $1(0.1)$ & 0 & $4(0.2)$ & $1(0.03)$ & 0 & $6(0.1)$ & $\begin{array}{l}\chi^{2}=4.63, d f=4 \\
p=0.327\end{array}$ \\
\hline Total & $256(31.6)$ & $284(41.6)$ & $722(32.9)$ & $556(24.3)$ & $272(23.8)$ & $2090(29.3)$ & $\begin{array}{l}\chi^{2}=110, d f=4 \\
p<0.001^{*}\end{array}$ \\
\hline
\end{tabular}

Figures in parenthesis indicate percentage; $\chi^{2}$ value, df-degrees of freedom, ${ }^{*}$ Significant as $P<0.05$ using Chi-square test 
and irregular menstruation (5.6\%) were more common in young adults, and it was statistically significant

Table 6 depicts the general symptoms of females not classified elsewhere. Headache (13.4\%) was the most common symptoms followed by fever (6\%) and weakness (2.7\%). Fever (19.9\%), ear pain $(2.2 \%)$, and loss of appetite $(2.5 \%)$ were more common in children compared to other age groups, and it was found statistically significant for all three symptoms $(\mathrm{p}<0.001)$. Headache $(25.2 \%)$ was the most common symptom in adolescents compared to others. Weakness (4.2\%), visual impairment (2.3\%), watering of eyes (3.1\%), and eye pain $(1.7 \%)$ were more common in the age group of above 60 years, and it was statistically significant for all four symptoms.

Fig. 1 depicts 10 common symptoms reported by the study subjects and Fig. 2 shows the prevalence of system-wise symptoms among the study subjects. Both figures depict that there is a predominance of symptoms of the musculoskeletal system.

Majority 4,906 (68.9\%) females had only one symptom at presentation, whereas some subjects also had two or more symptoms (Fig. 3).

To study the association between number of symptoms reported by the subjects and age group, subjects were categorized into two groups. The Chi-square test was used to study the association and odds ratio (OR) value of $>1$ was considered having a positive association. Age group was associated with a number of symptoms reported. As the age advances, the odds of getting two or more symptoms increased from OR of 1.1 in the children to OR of 2.59 in the age group of 60 and above (Table 7).

\section{DISCUSSION}

Of the total 7,124 female patients who attended the mobile clinic, onefifth $(21 \%)$ of them were children and adolescents. Over 60\% (62.9\%) belongs to the age group of $20-59$ years and about one-sixth (15.9\%) of them were 60 and above age group. Symptoms associated with the musculoskeletal system $(72.6 \%)$ were the most common health problem in our study followed by general symptoms (29.3\%) and symptoms of the circulatory and respiratory system (27.1\%). A study done by Rayamajhi et al. [5] among female patients attending free health camp showed that musculoskeletal system was the common system affected, followed by the digestive system, genitourinary system, and respiratory system. In the present study, the top six most common symptoms among female patients were myalgia, low back pain, nasal congestion, headache, knee pain, and abdominal pain.

In the present study, about $68.9 \%$ of patients had a single symptom, about one-fourth of patients had two symptoms, and $5.4 \%$ of the patients had three or more symptoms. Very similar findings were reported by Pambos et al. [6] that among patients attending health camp, 63.4\% had one diagnosis, $25.8 \%$ had two diagnoses, and $4.3 \%$ had three or more diagnosis. In contrast, a study done by Kroenke et al. [7], in 1997, showed $21 \%$ had one symptom, $23 \%$ had $2-3$ symptoms, and $56 \%$ had three or more symptoms and Marple et al. [8] showed 25\% had one symptom, $30 \%$ had two three symptoms, and $45 \%$ had more than three symptoms.

Five common symptoms of children reported in our mobile clinic were nasal congestion (41.3\%), fever (19.9\%), cough (13.7\%), abdominal pain $(7.2 \%)$, and skin rash. About $81.1 \%$ of them had a single symptom, and $16.6 \%$ had two symptoms. Vervoort et al. [9] reported that in terms of frequency, headache, stomachache, and pain in joints, followed by muscle fever and vomiting or upset stomach are the most regularly occurring symptoms in children. Skuse et al. in his study [10] had reported that in the general population $2-10 \%$ of children complain of stomach ache, joint pains, and headache. Bisht et al. [11] reported pain abdomen, headache, chest pain, and vomiting to be the common somatoform disorder among children.

Table 7: Association between number of symptoms reported by the subjects and age group

\begin{tabular}{|c|c|c|c|c|}
\hline \multirow[t]{2}{*}{ Age group (Years) } & \multicolumn{2}{|c|}{ Number of symptoms } & \multirow[t]{2}{*}{ OR $(95 \% \mathrm{CI})$} & \multirow[t]{2}{*}{$\chi^{2}, \mathbf{d f}$ and $P$ value } \\
\hline & Singlen (\%) & Two or moren (\%) & & \\
\hline $0-9$ & $662(81.6)$ & 149 (18.3) & 1 & \\
\hline $10-19$ & $547(80.1)$ & $136(19.8)$ & $\begin{array}{l}1.10,(0.85- \\
1.4)\end{array}$ & $\chi^{2}=0.57, \mathrm{df}=1, P=0.45$ \\
\hline $20-39$ & $1438(64.5)$ & $759(34.5)$ & $\begin{array}{l}2.34,(1.92- \\
2.86)\end{array}$ & $\chi^{2}=73, \mathrm{df}=1, P=0.0001^{*}$ \\
\hline $40-59$ & $1534(66.9)$ & $756(32.9)$ & $\begin{array}{l}2.19,(1.79- \\
2.69)\end{array}$ & $\chi^{2}=62.1, \mathrm{df}=1, P=0.0001^{*}$ \\
\hline$\geq 60$ & $725(63.4)$ & $424(36.5)$ & $\begin{array}{l}2.59,(2.09- \\
3.22)\end{array}$ & $\chi^{2}=78.9, \mathrm{df}=1, P=0.0001^{*}$ \\
\hline
\end{tabular}

Figures in parenthesis indicate percentage; $\chi^{2}$ value, df-degrees of freedom, *Significant as $P<0.05$ using Chi-square test, OR: Odds ratio. CI: Confidence interval

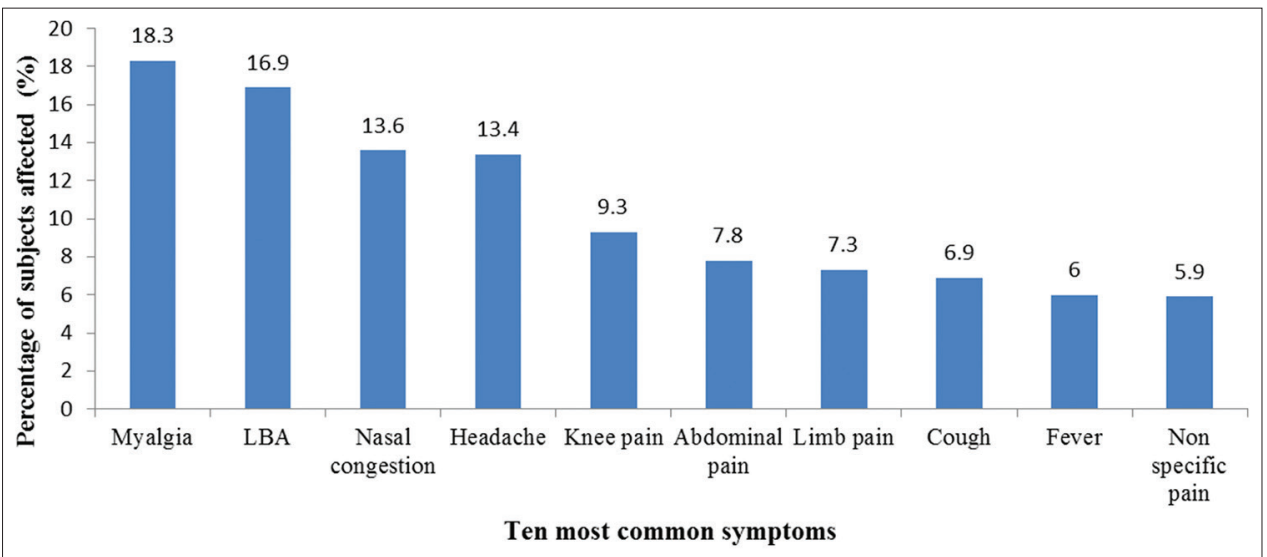

Fig. 1: Ten most common symptoms reported by the study subjects. Numbers indicate the percentage of subjects affected; LBA: Low backache 


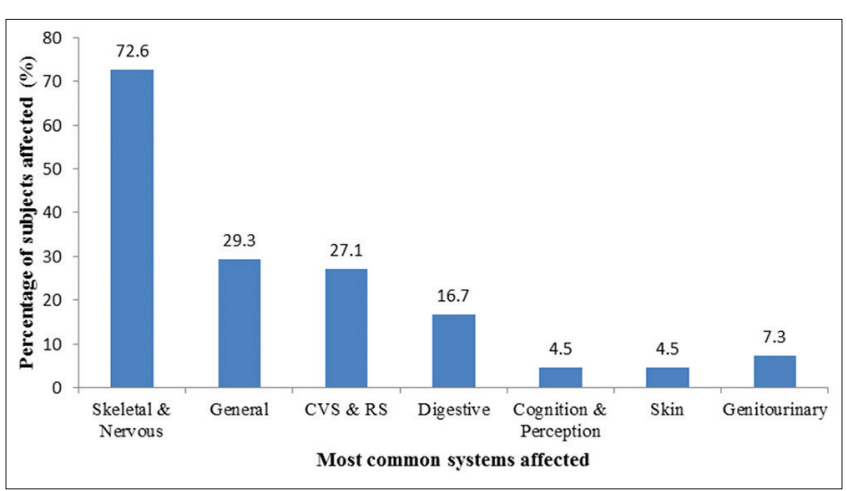

Fig. 2: Common systems affected among the study subjects. Numbers indicate the percentage of subjects affected; CVS: Cardiovascular system; RS: Respiratory system

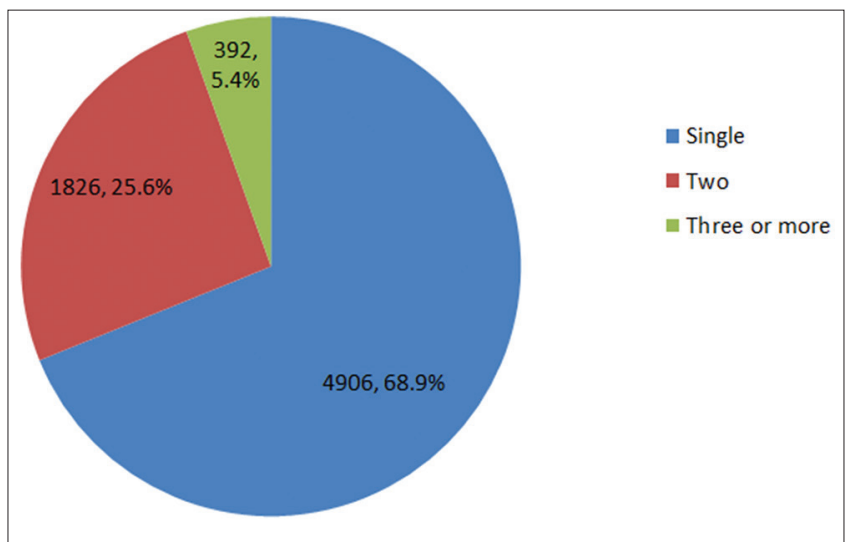

Fig. 3: Number of symptoms reported by the study subjects

Five common symptoms of adolescents reported were low back pain (25.5\%), headache (25.2\%), abdominal pain (17.7\%), nasal congestion $(17.7 \%)$, and cough $(7.7 \%)$. Mohapatra et al. [12] had reported in his study with $10 \%$ of teenagers reporting frequent headaches. Haugland et al. [13] reported in the study conducted by cross-national survey by the WHO among adolescent showed headache, followed by abdominal pain, backache, dizziness, low energy, irritability, nervousness, and sleep difficulties. Five common symptoms of adults in the age group of $20-39$ years were low back pain $(23.4 \%)$, myalgia (16.5\%), epigastric pain (14.9\%), nasal congestion (13.2\%), and headache (11.7\%).

Five common symptoms of adults in the age group of 40-59 years were myalgia (24.2\%), low back pain (16.4\%), knee pain (15.2\%), upper and lower limb pain (10\%), and only leg pain (7.6\%). Similar findings were reported by Pambos et al. [6] that among the patients who attended the rural health camp, stomach pain (20.1\%), musculoskeletal pain (11.8\%), osteoarthritis (7.4\%), and visual problems (6.1\%) as most commonly occurring problems in adults. Krantz and Östergren [14] reported that among middle-aged women the common symptoms were joint pain, followed by muscular tension, tiredness, and low back pain in Swedish.

Five common symptoms of geriatric population above the age of 60 years were myalgia followed by knee pain, low back pain, and joint pain. A similar finding of the predominance of symptoms of musculoskeletal system was reported by Rayamajhi et al. [5] among the elderly population in Nepal attending free health camp. Hilderink et al. [15] reported joint pain, intestinal problems, and back pain being the common somatic complaints among the geriatric population. Similar findings were reported by Thygesen et al. [16] where the common complaints of the geriatric were musculoskeletal, gastrointestinal, and respiratory and allergy problems. Sha et al. [17] reported that musculoskeletal, fatigue, back pain, shortness of breath, and difficulty in sleep were the common symptoms above the age of 60 years.

Musculoskeletal system was the most common system affected in the adult females in the age group of $20-39$ and $40-59$ years $(74.5 \%$ and $95.6 \%$, respectively) and geriatric population (90.6\%). In case of children the respiratory and circulatory system symptoms (57.4\%) and case of adolescents, general symptoms were more common (35.1\%).

\section{Limitation}

The limitation of the study was that the study had been done among the health seekers of a medical camp. It represents only the tip of the iceberg, and moreover, severe cases usually may not attend the medical camp. Thus, the prevalence of symptoms in this study may not be extrapolated to a larger population.

\section{CONCLUSION}

In the present study, about two third of the women who have attended the mobile clinic complain of symptoms related to a musculoskeletal system consisting of myalgia, low back pain, knee pain headache, and limb pain. Approximately one-third of the subjects complained of symptoms of the respiratory system such as nasal congestion, cough, and fever. This makes a large number of patients with physical symptoms that have no clear medical conditions, and most of these symptoms were self-limiting. Furthermore, these conditions can be managed at the primary care center itself and do not require specialty care, thus reducing the considerable burden on the tertiary hospitals. Thus, an effective protocol for management of these physical conditions with no medical problems at primary care level has to be evolved in a resource constraint country like India to effectively use the limited health-care resources.

\section{AUTHORS' CONTRIBUTIONS}

Logaraj M has provided the design, intellectual content, literature search, data analysis, manuscript review, and logistics support for the study. Sathiyanarayanan S, contributed for collecting data, statistical analysis, and manuscript writing. Balaji R helped in data collection, literature search, data analysis, and review.

\section{CONFLICTS OF INTEREST}

The authors declare that there are no conflicts of interest regarding the publication of this article.

\section{FUNDING}

The Department of Community Medicine, SRM Medical College Hospital, and Research Centre supported the conduct of the study.

\section{REFERENCES}

1. Kroenke K, Mangelsdorff AD. Common symptoms in ambulatory care: Incidence, evaluation, therapy, and outcome. Am J Med 1989;86:262-6.

2. Cheema E, Sutcliffe P, Singer RJD. Community pharmacist-led new medicine service for patients with a long term medical condition: A cross-sectional study. Int J Pharm Pharm Sci 2017;9:129-33.

3. Last J. The iceberg: Completing the clinical picture in general practice. Lancet 1963;282:28-31.

4. Mekonnen AB, Bhagavathula AS. Inappropriate medication use in the elderly population attending gondar university hospital: A Preliminary Assessment. Int J Pharm Pharm Sci 2014;6:540-3.

5. Rayamajhi R, Yadav D, Ghimire A, Khanal V, Tamrakar D, Shrestha A, et al. A descriptive study on morbidities of patients attending free health camp in Sankhejung Vdc of Ilam District, Nepal. J Chitwan Med Coll 2013;3:48-51.

6. Pambos M, Jessica NG, Loukes J, Matheson J, Aryal B, Adhikari S, et al. Demographics and diagnoses at rural health camps in Nepal: Cross-sectional study. Fam Pract 2012;29:528-33.

7. Kroenke K, Jackson JL, Chamberlin J. Depressive and anxiety disorders in patients presenting with physical complaints: Clinical predictors and outcome. Am J Med 1997;103:339-47. 
8. Marple RL, Kroenke K, Lucey CR, Wilder J, Lucas CA. Concerns and expectations in patients presenting with physical complaints. Frequency, physician perceptions and actions, and 2-week outcome. Arch Intern Med 1997;157:1482-8.

9. Vervoort T, Goubert L, Eccleston C, Bijttebier P, Crombez G. Catastrophic thinking about pain is independently associated with pain severity, disability, and somatic complaints in school children and children with chronic pain. J Pediatr Psychol 2006;31:674-83.

10. Skuse D, Bruce H, Dowdney L, Mrazek D. Somatisation and somatoform disorders. In: Child Psychology and Psychiatry: Framework for Practice. $2^{\text {nd }}$ ed. New Jersey: John Wiley and sons ltd; 2011.

11. Bisht J, Sankhyan N, Kaushal RK, Sharma RC, Grover N. Clinical profile of pediatric somatoform disorders. Indian Pediatr 2008;45:111-5.

12. Mohapatra S, Deo SJ, Satapathy A, Rath N. Somatoform disorder in children and adolescents. Ger J Psychiatry 2014;17:19-24.

13. Haugland S, Wold B, Stevenson J, Aaroe LE, Woynarowska B. Subjective health complaints in adolescence. A cross-national comparison of prevalence and dimensionality. Eur J Public Health 2001;11:4-10

14. Krantz G, Östergren P. Common symptoms in middle aged women: Their relation to employment status, psychosocial work conditions and social support in a Swedish setting. J Epidemiol Community Health 2000;54:192-9.

15. Hilderink PH, Benraad CE, van Driel D, Buitelaar JK, Speckens AE, Olde Rikkert MG, et al. Medically unexplained physical symptoms in elderly people: A pilot study of psychiatric geriatric characteristics. Am J Geriatr Psychiatry 2009;17:1085-8.

16. Thygesen E, Lindstrom TC, Saevareid HI, Engedal K. The subjective health complaints inventory: A useful instrument to identify various aspects of health and ability to cope in older people? Scand J Public Health 2009;37:690-6.

17. Sha MC, Callahan CM, Counsell SR, Westmoreland GR, Stump TE, Kroenke K, et al. Physical symptoms as a predictor of health care use and mortality among older adults. Am J Med 2005;118:301-6. 